\title{
KONCEPCJA PATH DEPENDENCE W EKONOMII
}

\section{Streszczenie}

Cel - Celem artykułu jest przedstawienie genezy oraz znaczenia koncepcji path dependence $\mathrm{w}$ badaniach ekonomicznych.

Metodyka badań - Metody badawcze zastosowane w trakcie przygotowania niniejszego artykułu obejmują analizę i krytykę dorobku literatury przedmiotu w zakresie nowej ekonomii instytucjonalnej, dotyczące koncepcji zależności od ścieżki. Posłużyły temu konstrukcje i analizy logiczne, przede wszystkim interpretacje modeli teoretycznych w kontekście teorii, dotychczasowego stanu badań związanych z zastosowaniem koncepcji.

Wynik - Koncepcja zależności od ścieżki stanowi swego rodzaju remedium, gdyż pozwala wyjaśnić przypadki, które przeczą przewidywaniom dotychczas stosowanych teorii lub są niemożliwe do wytłumaczenia z ich perspektywy.

Oryginalność/wartość - Koncepcja path dependence, stworzona w ramach nowej ekonomii instytucjonalnej, otwiera nowy aparat analityczny do badania wielu procesów gospodarczych i społecznych. Zwraca uwagę na fakt, iż niejednokrotnie przypadkowe i z pozoru mało znaczące wydarzenia w przeszłości zasadniczo wpływają na przebieg całego procesu. Koncepcja zależności od ścieżki pozwala uporządkować wydarzenia społeczno-gospodarcze w sekwencję o charakterze wyjaśniającym.

Słowa kluczowe: nowa ekonomia instytucjonalna, koncepcja zależności od ścieżki, instytucje

\section{THE PATH DEPENDENCE CONCEPT IN ECONOMY}

\section{Summary}

Goal - The aim of the article is to explain how the concept of the path dependence can be used in economy research.

Research methodology - Analysis and criticism of the subject matter literature in the field of new institutional economics regarding the concept of path dependency. It was supported by logical constructions and analyzes, first of all interpretations of theoretical models in the context of the theory, the current state of research related to the application of the concept.

Score - The concept of path dependence allows to explain cases that are impossible to explain from the perspective of current economic theories.

Originality /value - The concept is created as part of the new institutional economy, opens up a new analytical apparatus for studying many economic and social processes. The concept of path dependence allows us to organize social and economic events into an explanatory sequence. These events may hinder or exclude the possibility of achieving certain states at future 
stages of institutional development. In otherwords, some development paths, such as optimal for the community, may be blocked or difficult to choose.

Keywords: new institutional economy, path dependence, institution

DOI: $10.15290 /$ wpewbmn4.2020.01

\section{Wprowadzenie}

Koncepcja path depencence, czyli zależności od ścieżki, jest ideą ukształtowaną na gruncie ekonomii w latach 80. XX wieku przez Briana Arthura i Paula Davida jako alternatywa do ortodoksyjnego widzenia rozwoju gospodarczego. Koncepcja ta była odpowiedzią na fakt, iż zdaniem badaczy, niektórych trudno odwracalnych procesów społecznych oraz gospodarczych nie można wyjaśnić za pomocą istniejących teorii ekonomicznych. Koncepcja zależności ścieżkowej stanowi swego rodzaju remedium, gdyż pozwala wyjaśnić przypadki, które przeczą przewidywaniom dotychczas stosowanych teorii lub są niemożliwe do wytłumaczenia z ich perspektywy.

\section{Istota i geneza koncepcji path dependence}

Podłożem do sformułowania koncepcji zależności od ścieżki była próba uchwycenia zjawiska rosnących przychodów na gruncie ekonomii głównego nurtu, przede wszystkim jednak brak perspektywy analitycznej, pozwalającej pogodzić zjawisko rosnących przychodów z modelem doskonałej konkurencji. Nowa koncepcja miała również na celu wyjaśnienie ułomności rynkowego mechanizmu alokacyjnego, trudnego do wytłumaczenia w ujęciu ekonomii ortodoksyjnej ${ }^{1}$. Zdaniem B. Arthura i P. Davida mechanizm wolnorynkowy w szczególnych okolicznościach prowadzi do upowszechnienia się gorszego produktu, mimo że istnieją dobra alternatywne, zaspokajające tę samą potrzebę ${ }^{2}$. Wbrew ugruntowanym przez klasyków w rozważaniach ekonomicznych przesłaniom, dominacja gorszego standardu może utrzymywać się przez dłuższy czas ${ }^{3}$.

Badacze poddali analizie przyczyny tego zjawiska i wykazali, że o sukcesie określonego rozwiązania niejednokrotnie przesądziła przewaga zdobyta na początkowym etapie rozwoju danej gałęzi produkcji. Źródłem tej przewagi mogły być pojedyncze i z pozoru nieznaczące wydarzenia, jednostkowe wybory, a także

\footnotetext{
1 J. Dzionek-Kozłowska, Transformacja ustrojowa $z$ perspektywy koncepcji path dependence, „Prace Naukowe Uniwersytetu Ekonomicznego we Wrocławiu”, nr 74, s. 214-215.

2 B. Arthur, Competing Technologies, Increasing Returns, and Lock-in by Historical Small Events, „Economic Journal”, 1989, vol. 99, no. 394; P. David, Clio and the Economics of QWERTY, „American Economic Review" 1985, vol. 75, no. 2.

3 J.R. Commons, Institutional Economics. Its Place in Political Economy, „Transaction Publishers”, t. 1, New Brunswick \& London 1990, s. 146; W. Stankiewicz, Ekonomika instytucjonalna. Zarys wykładu, Wydawnictwo Prywatnej Wyższej Szkoły Businessu i Administracji, Warszawa 2012, s. $45-54$.
} 
czynniki przypadkowe, jak miało to miejsce przy upowszechnieniu się na całym świecie klawiatury typu QWERTY4. Tego rodzaju mechanizm uwarunkowany jest pozytywnym sprzężeniem zwrotnym, gdyż każdorazowe dokonanie przez nabywcę wyboru dobra opartego na określonej technologii zwiększa prawdopodobieństwo, że zostanie ono nabyte po raz kolejny - standaryzacja w ostatecznym rozrachunku prowadzi do dominacji jednego rozwiązania, czyli zablokowania innych, osiągalnych w punkcie wyjścia dróg rozwoju danej branży.

Koncepcja zależności od ścieżki silnie związana jest z nurtem nowej ekonomii instytucjonalnej i została przyjęta za narzędzie wyjaśniania sposobu tworzenia się instytucji w życiu społeczno-gospodarczym. Należy zaznaczyć, iż koncepcja ta jest raczej podejściem badawczym, który pozwala interpretować trudno odwracalne, bądź też nieodwracalne procesy ekonomiczne, społeczne i przestrzenne ${ }^{5}$, natomiast sam termin path dependence jest bezpośrednio inkorporowany z nauk ścisłych. Koncepcja i zjawisko, którego dotyczy, przez polskich autorów określane jest mianem: „ścieżek rozwojowych”, „samowarunkujących się ścieżek rozwoju”, „trajektorii rozwojowych”, „zależności ścieżkowej”, „uzależnienia od dotychczasowej ścieżki rozwoju”, „zależności od szlaku” lub nawet „pułapki gorszego produktu”.

Warto dodać, iż termin path dependence po raz pierwszy w języku polskim pojawił się w tłumaczeniu pracy R. Putnama w 1995 roku jako „zależność od szlaku”6. W tym samym brzmieniu stosuje ten termin ekspert G. Ekiert przy badaniu prawidłowości przemian ustrojowych i gospodarczych w Europie Środkowo-Wschodniej$^{7}$. Jednakże zdaniem K. Gwosdza lepszym brzmieniem oddającym ducha koncepcji jest tłumaczenie path dependence jako „zależności od ścieżki”. Podążając tym tropem, tak skonstruowany termin koncepcji występuje w pracach polskich geografów m.in. B. Domańskiego i K. Szmigiel-Rawskiej.

\footnotetext{
4 Rozstawienie klawiszy proponowane przez Sholesa znalazło poważną konkurencję w 1932 roku, kiedy to pewien amerykański psycholog z Uniwersytetu w Seattle opracował zupełnie nowy układ, który to miał zagwarantować piszącemu znacznie szybszą pracę. August Dvorak zepchnął najrzadziej używane litery do najniższego rzędu, natomiast te, którymi operujemy najczęściej przesunął na środek oraz na prawą stronę, gdyż większość ludzi to osoby praworęczne. Takie rozwiązanie, mimo że faktycznie znacznie usprawniało pisanie, nie przyjęło się tak dobrze, jakby chciał jego pomysłodawca, aczkolwiek większość współczesnych systemów operacyjnych pozwala użytkownikom na zmianę standardowego rozstawienia klawiszy QWERTY na układ proponowany przez Augusta Dvoraka. Zdaniem Paula Davida lepszym rozwiązaniem była klawiatura Dvoraka, gdyż faktycznie te rozwiązanie pozwalałoby zwiększyć tempo pisania i byłoby łatwiejsze do opanowania; P. David, Clio and the Economics..., s. 332-333.

5 K. Gwosdz, Koncepcja zależności od ścieżki (path dependence) w geografii społeczno-ekonomicznej, „Przegląd Geograficzny” 2004, t. 76, z. 4, s. 433-435.

6 R. Putnam, Demokracja w działaniu: Tradycje obywatelskie we wspótczesnych Włoszech, Społeczny Komitet Wydawniczy ZNAK, Kraków, Fundacja im. Stefana Batorego, Warszawa 1995, s. 97-99.

7 G. Ekiert, Prawidłowości transformacji w Europie Wschodniej, „Studia socjologiczne” 2000, nr 158(3), s. 11-41.

8 B. Domański, Kapitał zagraniczny $w$ przestrzeni Polski. Prawidłowości rozmieszczenia, uwarunkowania $i$ skutki, Instytut Geografii i Gospodarki Przestrzennej Uniwersytetu Jagiellońskiego, Kraków 2001; K. Szmigiel-Rawska, Koncepcja zależności od ścieżki jako narzędzie wyjaśniania $w$ badaniach ekonomicznej geografii politycznej, „Prace i Studia Geograficzne” 2014, t. 54, s. 149-161.
} 
Idea ścieżek rozwoju jest ściśle powiązana z propozycją badawczą, obecną od dziesięcioleci, uznającą znaczenie historii rozwoju instytucji ekonomicznych za istotne w zrozumieniu mechanizmów rozwoju procesów gospodarczych. Procesy charakteryzujące się zależnością ścieżkową są „wrażliwe na własną historię, czyli ich trajektoria rozwoju uzależniona jest od ich dotychczasowego przebiegu. Niektórych procesów nie da się wyjaśnić bez sięgnięcia do historii ich przebiegu. Częstym wyrazem tego stanowiska jest używanie przez zwolenników tego podejścia określenia history matters (historia ma znaczenie) ${ }^{9}$.

Zaletą koncepcji path dependence jest połączenie generalnych prawidłowości ze szczegółami historycznymi. Podejście zależności od ścieżki pozwala badaczom połączyć oraz uporządkować znane procesy i zjawiska we wspólny wyjaśniający wzorzec, który odpowiada na pytanie dlaczego proces potoczył się w takim a nie innym kierunku i dlaczego kierunek ten jest utrzymywany, mimo że istnieją inne drogi rozwoju?. Zatem myślenie w ujęciu koncepcji path dependence jest konieczne w celu wyjaśnienia zjawiska, gdy liczne możliwości rozwiązania w pewnych momentach, uwarunkowanych historycznie, okazały się trudne do skopiowania winnych.

Ze względu na zakres interpretowanych procesów koncepcje zależności od ścieżki można podzielić na dwa nurty: szeroki i wąski. W ujęciu szerokim koncepcja path dependence obejmuje wyjaśnienie związków pomiędzy najważniejszymi decyzjami z przeszłości a stanem aktualnym oraz przyszłym w danym łańcuchu wydarzeń ${ }^{10}$. To znaczy, że zdarzenie z przeszłości wpływa na późniejsze wyniki w możliwej sekwencji wydarzeń, przy szczególnym uwzględnieniu ograniczeń obranego kierunku rozwoju. Podstawowe znaczenie ma historia, ponieważ jeśli wydarzenia we wcześniejszych fazach obrałyby inny tor, to zostałyby one utrwalone w dalszych etapach rozwoju. Dlatego też ujęcie koncepcji w nurcie szerokim jest zarazem ponownym odkryciem roli historii w naukach społecznych, która jest zazwyczaj ignorowana na gruncie wielu teorii ekonomicznych. Słabością ujęcia largo koncepcji path dependence jest fakt, że wnosi ono niewiele nowego ładunku teoretycznego, gdyż przypomina metody i podejście znanego w geografii kierunku historyczno-gospodarczego. Dotychczas zwrócenie uwagi na ograniczającą rolę historii w naukach społecznych wyrażano za pomocą starszych teorii - m.in. kumulatywnej przyczynowości, warstw inwestycji czy homeostazy systemów ${ }^{11}$.

W wąskim (inaczej formalnym) rozumieniu badacze zajmują się rozpoznaniem początkowych warunków, które nadały określonemu procesowi kierunek rozwoju. Początkowo identyfikowane są elementy odpowiadające za powstawanie ścieżki zależności. Wiąże się to $\mathrm{z}$ faktem, iż za pierwszy krok w procesie przyczynowo-skutkowym odpowiadają często nieprzewidziane bądź mało znaczące wydarzenia.

\footnotetext{
9 Ibidem, s. 439.

${ }^{10}$ J. Sukiennik, Path dependence - proces przekształceń instytucjonalnych, „Prace Naukowe Uniwersytetu Ekonomicznego we Wrocławiu" 2017, nr 493, s. 164-165.

${ }^{11}$ M. Jasiński, Teoria zależności od ścieżki a małe gospodarki wyspiarskie, „Zeszyty Naukowe”, Szkoła Główna Handlowa. Kolegium Gospodarki Światowej 2010, nr 28, s. 53.
} 
Wydarzenia te mają zazwyczaj właściwości deterministyczne, które wzmacniają daną ścieżkę rozwoju. Dodatkowo początek ścieżki rozpoczynający proces wyboru decyzji niekiedy nie bywa racjonalny, lecz jest wynikiem przypadku ${ }^{12}$. Nieprzewidzianymi wydarzeniami mogą być indywidualne decyzje, czy też wielkoskalowe losowe wydarzania (katastrofy naturalne, wojny czy załamania na giełdach), które jednocześnie zaprzeczają dotychczas przewidzianym teoretycznym rezultatom w ramach określonego modelu (wzorca wyjaśniającego).

Istotę procesu zależności od ścieżki w jej formalnym ujęciu odzwierciedla stochastyczny model, zwany popularnie urną Pólya ${ }^{13}$ :

- $\quad$ pierwsze wydarzenia we wczesnych fazach procesu mają duży wpływ na jego przebieg, a ponieważ mają one niezdeterminowany charakter, możliwych jest wiele stanów równowagi;

- czas, kiedy wydarzenie nastąpi, warunkuje znaczenie tego wydarzenia. Ponieważ zjawiska dziejące się we wstępnych fazach procesu mają większe znaczenie niż dziejące się później, wydarzenie, które nastąpi „zbyt późno", może nie mieć dużego znaczenia dla przebiegu procesu;

- mała elastyczność w dalszych fazach procesu prowadzi do zamknięcia na danej ścieżce. Im bowiem na późniejszym etapie procesu się znajdujemy, tym trudniej jest zmienić kierunek rozwoju.

Odwołując się do wyżej opisanych implikacji z przebiegu doświadczenia Pólyi, zależy zaznaczyć, iż proces zależności od ścieżki jest procesem nieergodycznym, gdyż tworzone są struktury w wyniku jej własnej ewolucji. Z kolei podatność danego procesy na zmiany zależy od fazy, w jakiej się on znajduje, ponieważ kierunek ścieżki jest określany specyficznym następstwem wydarzeń ${ }^{14}$.

\section{Znaczenie i zastosowanie koncepcji path dependence w badaniach ekonomicznych}

Metodologia ujęcia zależności od ścieżek sprowadza się do znalezienia momentu początkowego $\mathrm{w}$ trajektorii rozwoju oraz śledzenia procesów, które podtrzymują obrany kierunek. Twórcy koncepcji dowodzą, iż pierwsze wydarzenia mają kluczowe znaczenie dla rozwoju, gdyż determinują jego kształt i tylko na początku można zablokować rozwój ścieżki. Lock-in to stan, w którym pewien wybrany produkt (zachowanie, rozwiązanie) jest nieustannie powielane (kupowane). Powtarzalność ta jest wynikiem dążenia do obniżenia kosztów funkcjonowania na rynku oraz kosztów innego wyboru.

Zamknięcie na inne możliwości ma miejsce, gdy występują trudności w odzyskaniu nakładów poniesionych przy dostosowaniu produktu, czyli wysokich kosztów zatopionych na rzecz dostosowania kapitału rzeczowego i ludzkiego, a także

\footnotetext{
${ }^{12}$ K. Szmigiel-Rawska, Koncepcja zależności od ścieżki..., s. 155.

${ }^{13}$ G. Pólya, Sur quelques points de la théorie deprobabilités, „Annales de l'Institut Henri Poincaré” 1930, no. 1, s. 117-161.

${ }^{14}$ K. Gwosdz, Koncepcja zależności od ścieżki..., s. 438-440.
} 
wydatków na rzecz wzrostu efektywności. Zamknięcie w ścieżce uniemożliwia skorzystanie z innych, alternatywnych, niejednokrotnie lepszych rozwiązań ${ }^{15}$.

Zjawisko zamknięcia w ścieżce (lock-in) wiąże się z rosnącymi korzyściami skali oraz działaniem kumulujących się przychodów. Ma ono miejsce, gdy przyjęte rozwiązanie początkowe po pewnym czasie przynosi coraz większe korzyści, ograniczając tym samym możliwość alternatywnych rezultatów. Zjawisko kumulujących się przychodów powoduje zarówno pozytywne, jak i negatywne cykle rozwojowe, których odwrócenie bez interwencji z zewnątrz jest praktycznie niemożliwe. Zdaniem Arthura jedynym sposobem ucieczki z takiej pułapki jest interwencja jakiejś zewnętrznej siły lub szok rozwojowy, zmieniający strukturę systemu lub w radykalny sposób przekształcający wzajemne relacje zachodzące pomiędzy zaangażowanymi podmiotami ${ }^{16}$.

James Mahoney w artykule Path dependence in Historical Sociology (2000) dokonuje krytycznego przeglądu wyjaśnień o naturze historyczno-socjologicznej pod kątem zawartych w nich logik przyczynowości. Wyróżnia on dwa modelowe typy ścieżek: samowzmacniające i reakcyjne. Natura ścieżki samowzmacniającej opiera się na kumulatywności: sekwencja ma charakter samowzmacniający, gdy opiera się na powielaniu w czasie zdarzeń, które się na nią składają. Skutkiem zaistnienia określonego zdarzenia A będzie ponowne zaistnienie zdarzenia A. W typie ścieżki samowzmacniającej początkowe wydarzenie pobudza rozwój w danym kierunku i zostaje reprodukowane, dlatego też po pewnym czasie wzmocnienia ścieżki opuszczenie jej staje się niemal niemożliwe.

Natomiast w ścieżkach reakcyjnych nie następuje wzmacnianie wydarzeń początkowych, tylko ich przekształcanie. Ścieżki reakcyjne są sekwencjami czasowo uporządkowanymi w ciągu przyczynowo-skutkowym, w którym każde wydarzenie jest jednocześnie reakcją na wcześniejsze oraz przyczyną wydarzeń w przyszłości. Punktem początkowym w tego typu ścieżkach jest moment rozpoczynający sekwencję reakcyjną, w którym następuje połączenie kilku dotychczas oddzielnych sekwencji ${ }^{17}$.

Popularyzatorem koncepcji path dependence w naukach społecznych był noblista Douglas C. North, który dowiódł, że również na płaszczyźnie instytucjonalnej może dojść do ugruntowania się gorszego rozwiązania w ramach występowania rosnących przychodów. North posługuje się koncepcją zależności od ścieżki w celu wyjaśnienia przyczyn trudności szybkiego przekształcenia struktury układu instytucjonalnego. Noblista dowodzi, iż wytworzenie nowej instytucji wymaga czasu, zbudowania trwałych podstaw prawnych przy uwzględnieniu zasad nieformalnych $^{18}$. Dlatego też zmiana reguł gry w układzie instytucjonalnym wiąże się z niebezpieczeństwem pogorszenia się sytuacji społecznej oraz prawdopodobieństwem

\footnotetext{
${ }^{15}$ K. Szmigiel-Rawska, Koncepcja zależności od ścieżki ..., s. 153.

${ }^{16}$ J. Sukiennik, Path dependence - proces przeksztatceń instytucjonalnych..., s. 165.

17 J. Mahoney, Path dependence in historical sociology, „Theory and Society” 2000, vol. 29, s. $510-512$.

${ }^{18}$ D.C. North, Institutions, institutional change and economic performance. Political Economy of Institutions and Decisions, Cambridge University Press, New York 1990, s. 4-10.
} 
utraty nakładów poniesionych przy tworzeniu instytucji sprawdzających się w ówczesnych warunkach.

Douglas C. North przyczynił się do popularyzacji path dependence w sferze instytucji oraz wpłynął na wykorzystanie tejże koncepcji przez badaczy transformacji ustrojowej krajów Europy Środkowo-Wschodniej ${ }^{19}$. Dla badaczy transformacji ustrojowej byłych krajów socjalistycznych jest ona szczególnie atrakcyjna, ponieważ wykorzystują ją do objaśniania przyczyn w trudnościach związanych z procesem zmiany dotychczasowej ścieżki rozwojowej. Posługiwanie się nią jest pomocne przy wyjaśnianiu przyczyn trwałości określonych struktur i rozwiązań instytucjonalnych, charakterystycznych dla krajów byłego bloku wschodniego oraz trudności przy wprowadzaniu zmian ustrojowych. Analiza tego zjawiska przy pomocy koncepcji path dependence ukazuje niedopasowanie modelu rozwoju stworzonego w innym miejscu z czynnikami wewnętrznymi regionu, czyli przede wszystkim jakości kapitału ludzkiego i społecznego oraz historycznych uwarunkowań regionu „przyjmującego ścieżkę”, może prowadzić do negatywnego lock-in. Niedopasowanie zewnętrznego czynnika wywołującego ścieżkę z uwarunkowaniami wewnętrznymi ma negatywne konsekwencje w wymiarze zarówno gospodarczym, jak i społecznym i politycznym.

Koncepcja path dependence wykorzystywana jest także przez badaczy w geografii społeczno-ekonomicznej w celu wyjaśnienia mechanizmu rozwoju miast oraz wyjaśnienia genezy procesów lokalizacji działalności gospodarczej ${ }^{20}$. W tym ujęciu koncepcji problemy społeczno-gospodarcze miast mogą być pojmowane jako wynik wybranego w pewnym czasie rozwiązania, które następnie poprzez kolejne i przypadkowe zdarzenia jest wzmacniane, reprodukowane lub przekształcane. Ponieważ proces kształtowania się ewolucji każdego ośrodka miejskiego, jego funkcji oraz struktury przestrzennej i społecznej tworzy specyficzną ścieżkę rozwojową, każda faza rozwoju miasta jest silnie zależna od poprzedzających ją faz uwarunkowanych genetycznie i historycznie ${ }^{21}$.

\section{Podsumowanie}

Reasumując, koncepcja path dependence, stworzona w ramach nowej ekonomii instytucjonalnej, otwiera nowy aparat analityczny do badania wielu procesów gospodarczych i społecznych. Zwraca uwagę na fakt, iż niejednokrotnie przypadkowe i z pozoru mało znaczące wydarzenia z przeszłości znacząco wpływają na przebieg procesu. Koncepcja zależności od ścieżki pozwala uporządkować wydarzenia społeczno-gospodarcze w sekwencję o charakterze wyjaśniającym. Po ponad 30

\footnotetext{
${ }^{19}$ J. Dzionek-Kozłowska J., Transformacja ustrojowa z perspektywy..., s. 217-219.

${ }^{20}$ Przykładami zastosowania koncepcji path dependence w badaniach w ramach geografii ekonomiczno-społecznej przez polskich badaczy są Katarzyna Szmigiel-Rawska oraz Sylwia Dołzbłasz; K. Szmigiel-Rawska, Koncepcja zależności od ścieżki..., s. 149-161.

${ }^{21}$ E. Jaroszewska, M. Wieczorek, Przemiany starych miast przemysłowych $w$ kontekście koncepcji zależności od ścieżki (path dependence). Przykład Saint-Étienne i Watbrzycha, „Rozwój Regionalny i Polityka Regionalna" 2016, nr 32, s. 107-122.
} 
latach dyskusji wokół koncepcji path dependence liczba publikacji odnoszących się do tej problematyki jest niezwykle duża. Koncepcja ta zyskała w ostatnich latach popularność nie tylko w ekonomii, ale również w innych naukach społecznych: naukach politycznych, socjologii oraz geografii ekonomicznej. Pojawiła się swoista moda na poszukiwanie podobnych zależności w innych obszarach badawczych.

\section{Literatura}

Arthur B., Competing Technologies, Increasing Returns, and Lock-in by Historical Small Events, „Economic Journal” 1989, vol. 99, no. 394.

Commons J.R., Institutional Economics. Its Place in Political Economy, „Transaction Publishers", t. 1, New Brunswick \& London 1990.

David P., Clio and the Economics of QWERTY, „American Economic Review” 1985, vol. 75, no. 2.

Domański B., Kapitał zagraniczny w przestrzeni Polski. Prawidłowości rozmieszczenia, uwarunkowania i skutki, Instytut Geografii i Gospodarki Przestrzennej Uniwersytetu Jagiellońskiego, Kraków 2001.

Dzionek-Kozłowska J., Transformacja ustrojowa z perspektywy koncepcji path dependence, „Prace Naukowe Uniwersytetu Ekonomicznego we Wrocławiu. Ekonomia” 2009, nr 74.

Ekiert G., Prawidłowości transformacji w Europie Wschodniej, „Studia socjologiczne” 2013, nr 158.

Gwosdz K., Koncepcja zależności od ścieżki (path dependence) w geografii społeczno-ekonomicznej, „Przegląd Geograficzny” 2004, t. 76, z. 4.

Jaroszewska E., Wieczorek M., Przemiany starych miast przemysłowych $w$ kontekście koncepcji zależności od ścieżki (path dependence). Przykład Saint-Étienne i Watbrzycha, „Rozwój Regionalny i Polityka Regionalna” 2016, nr 32.

Jasiński M., Teoria zależności od ścieżki a małe gospodarki wyspiarskie, „Zeszyty Naukowe”, Szkoła Główna Handlowa. Kolegium Gospodarki Światowej 2010, nr 28.

Mahoney J., Path dependence in historical sociology, „Theory and Society” 2000, vol. 29.

North D.C., Institutions, institutional change and economic performance. Political Economy of Institutions and Decisions, Cambridge University Press, New York 1990.

Pólya G., Sur quelques points de la théorie deprobabilités, „Annales de l'Institut Henri Poincaré" 1930, no.1.

Putnam R., Demokracja $w$ działaniu: Tradycje obywatelskie we współczesnych Włoszech, Społeczny Komitet Wydawniczy ZNAK, Kraków, Fundacja im. Stefana Batorego, Warszawa 1995.

Stankiewicz W., Ekonomika instytucjonalna. Zarys wykładu, Wydawnictwo Prywatnej Wyższej Szkoły Businessu i Administracji, Warszawa 2012.

Sukiennik J., Path dependence - proces przekształceń instytucjonalnych, „Prace Naukowe Uniwersytetu Ekonomicznego we Wrocławiu" 2017, nr 493.

Szmigiel-Rawska K., Koncepcja zależności od ścieżki jako narzędzie wyjaśniania w badaniach ekonomicznej geografii politycznej, „Prace i Studia Geograficzne” 2014, t. 54. 